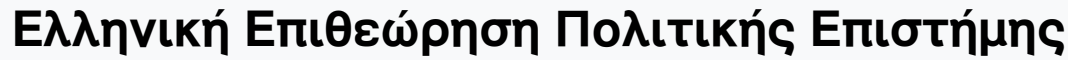

Tó 11 (1998)

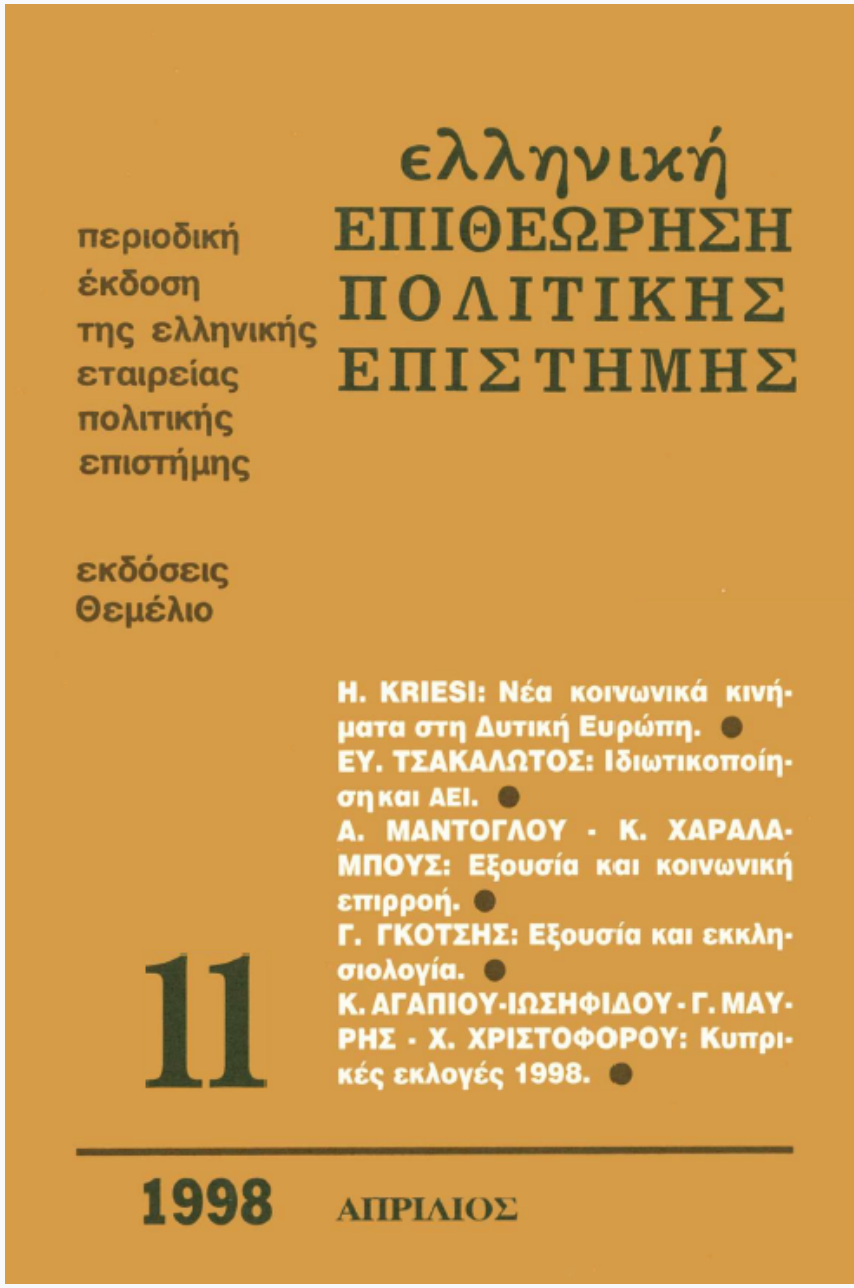

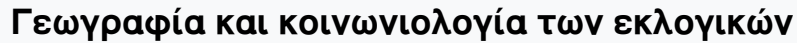

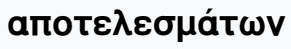

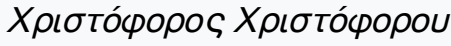

doi: 10.12681/hpsa.15121

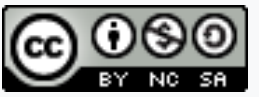

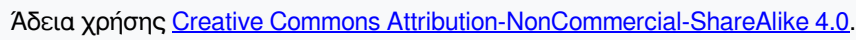

\section{Bıß入ıорачıкń avaчopá:}

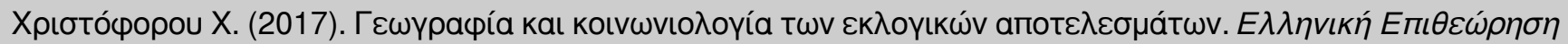

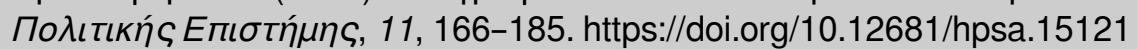




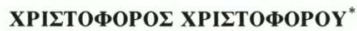

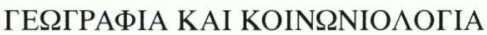

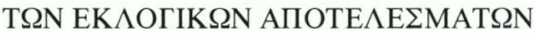

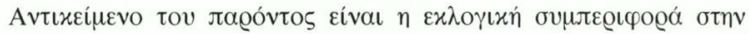

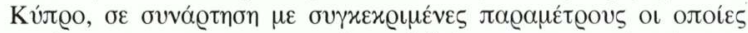

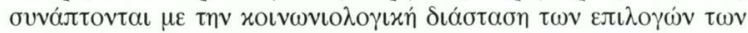

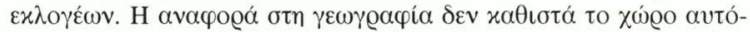

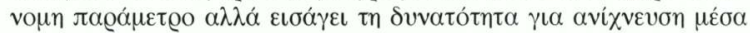

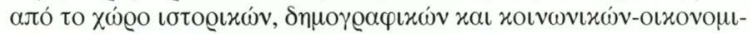

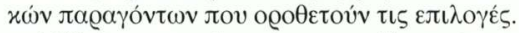

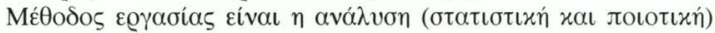

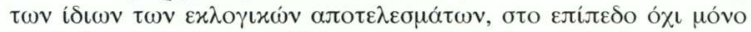

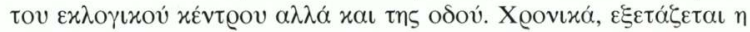

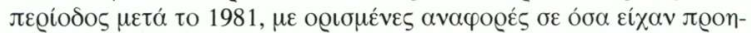
$\gamma \eta \theta \varepsilon i$.

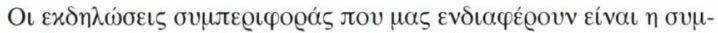

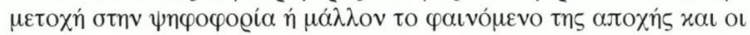

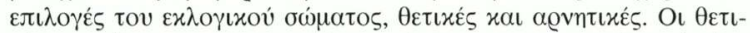

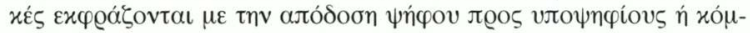

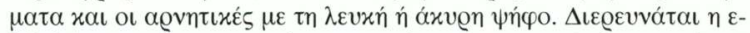

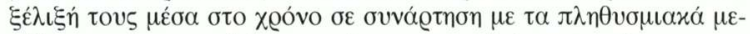

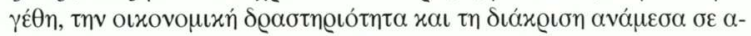

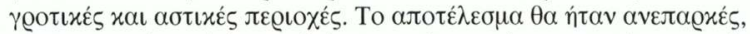

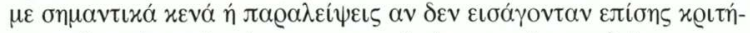

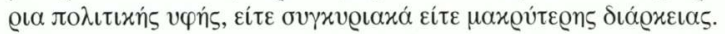

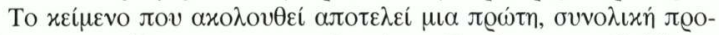

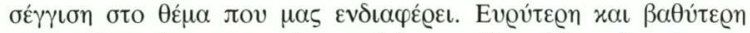

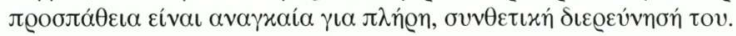

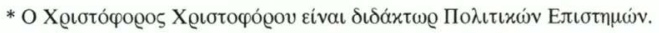




\section{H $\Sigma$ YMMETOXH}

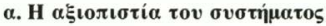

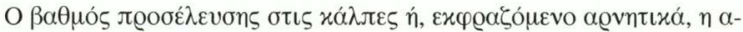

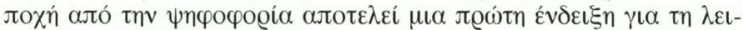

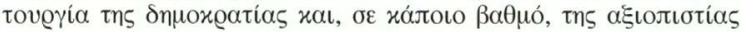

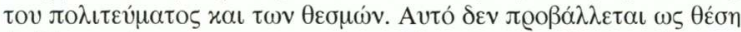

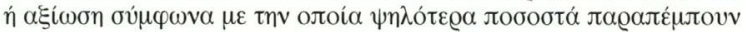

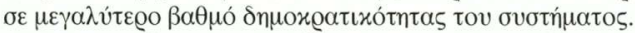

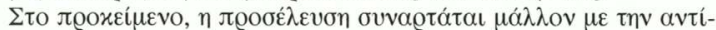

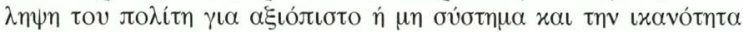

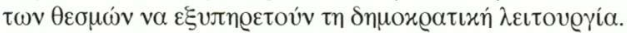

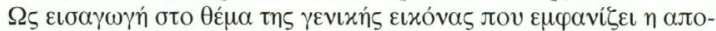

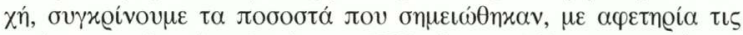

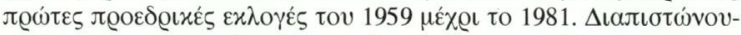

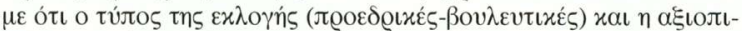

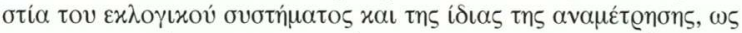

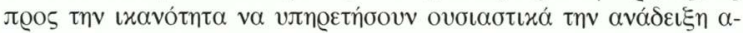

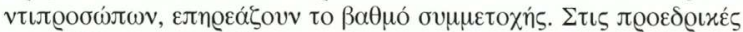

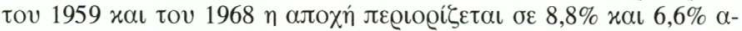

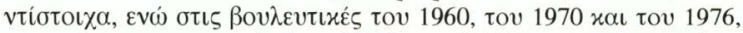

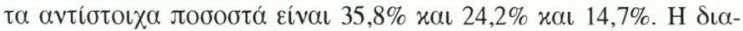

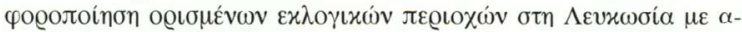

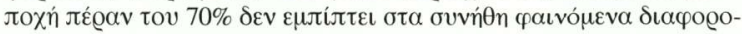

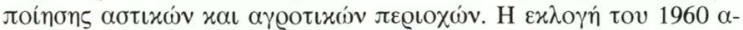

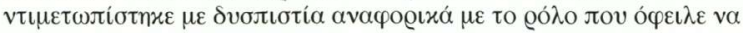

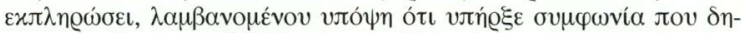

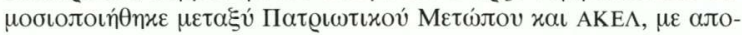

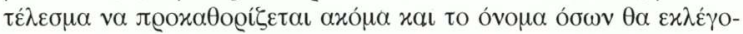
$v \tau \alpha$.

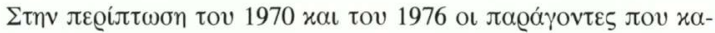

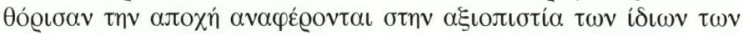

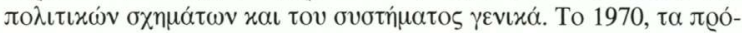

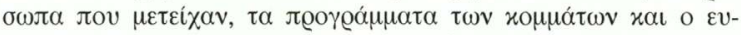

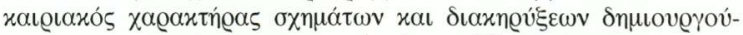

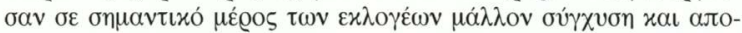

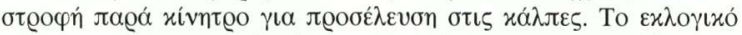

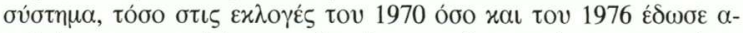

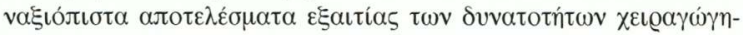




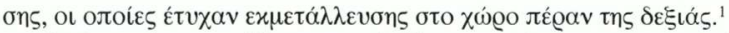

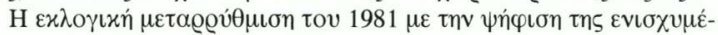

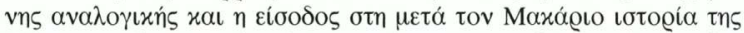

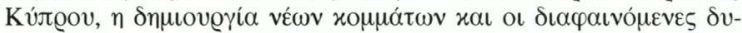

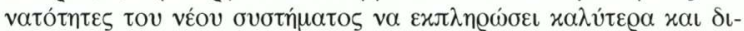

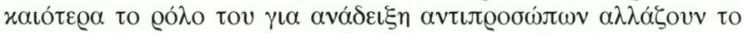

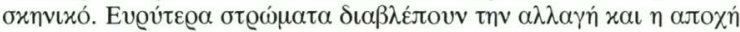

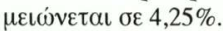

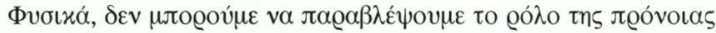

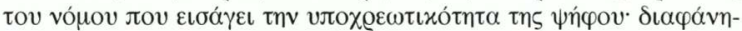

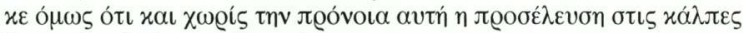

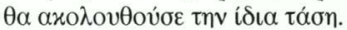

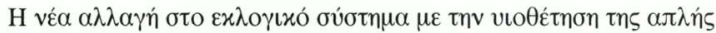

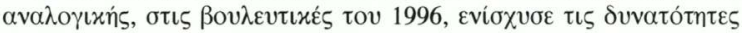

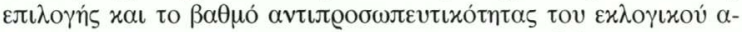

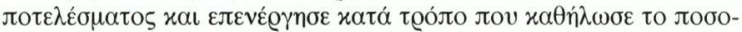

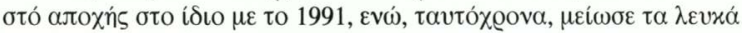

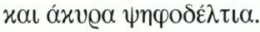

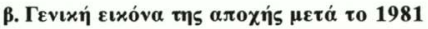

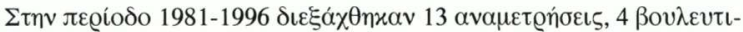

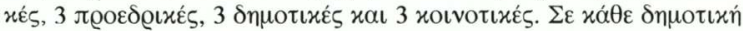

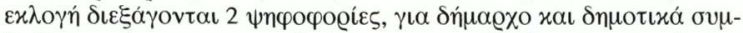

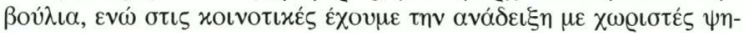

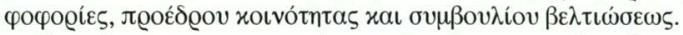

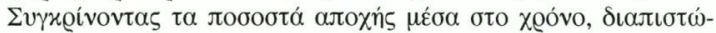

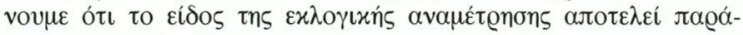

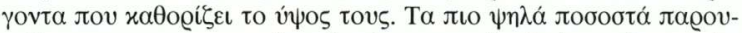

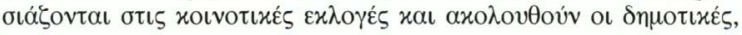

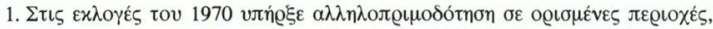

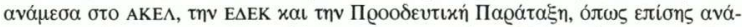

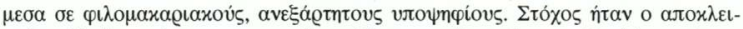

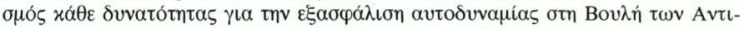

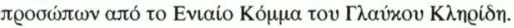

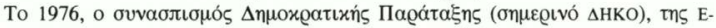

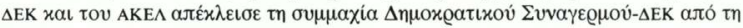

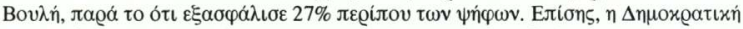

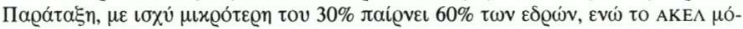

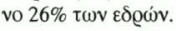




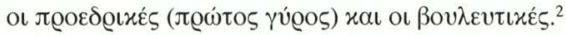

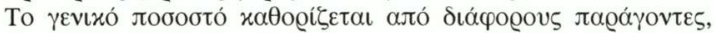

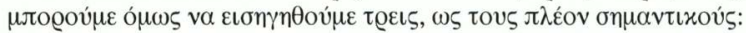

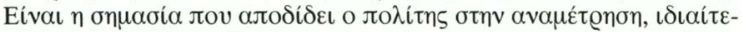

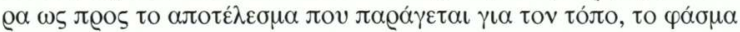

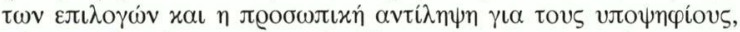

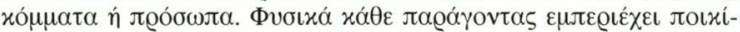

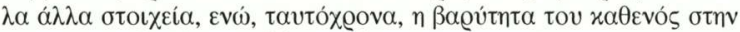

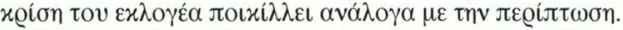

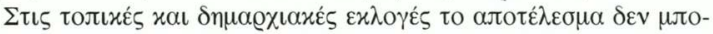

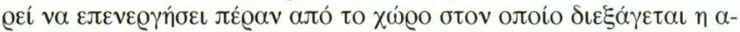

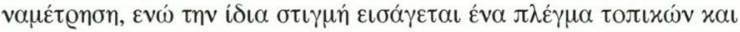

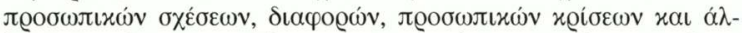

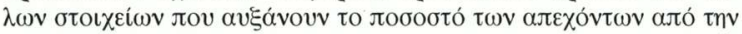

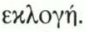

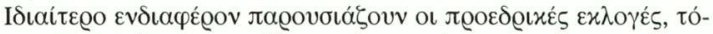

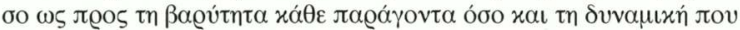

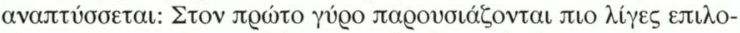

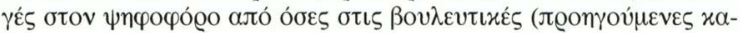

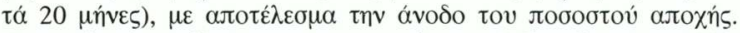

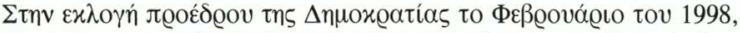

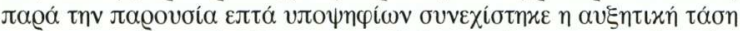

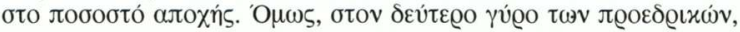

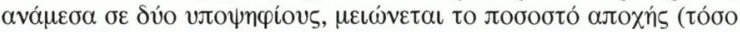

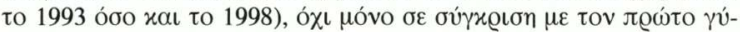

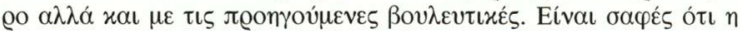

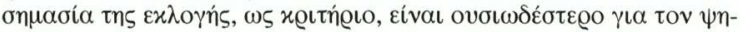

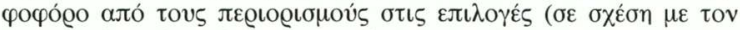

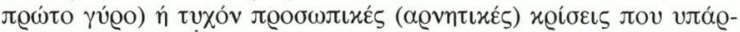

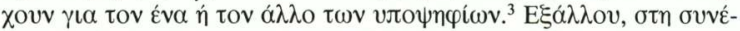

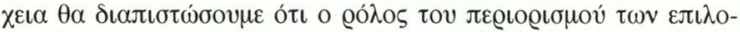

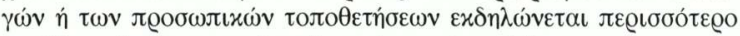

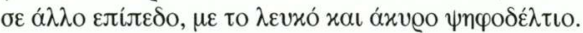

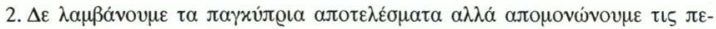

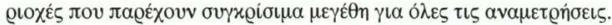

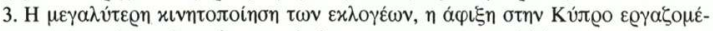

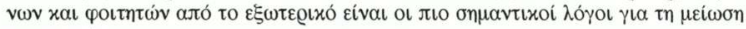
mऽ aлoxńs. 


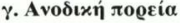

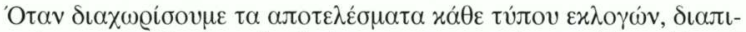

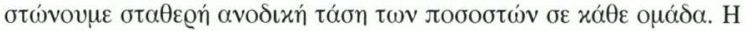

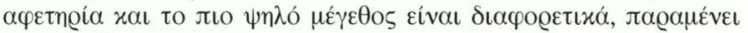

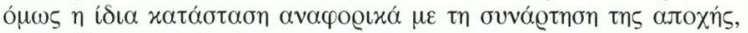

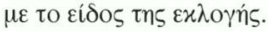

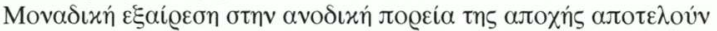

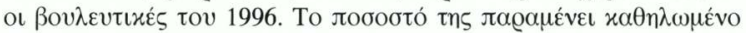

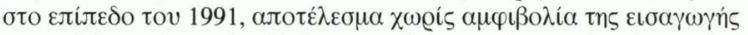

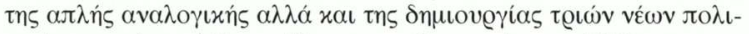

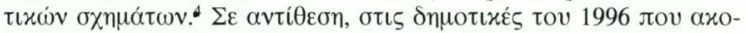

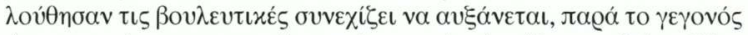

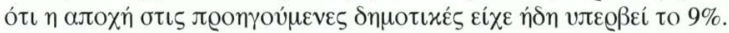

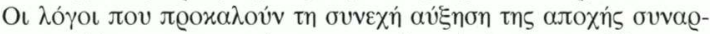

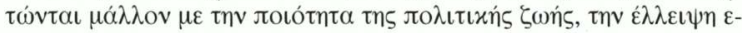

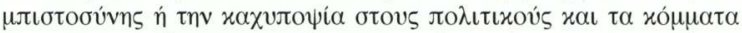

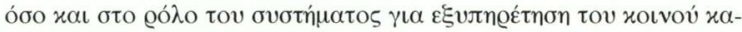

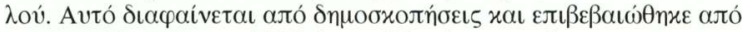

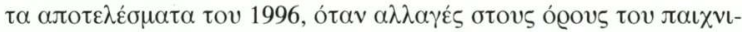

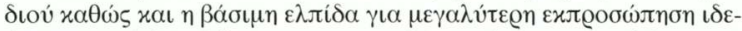

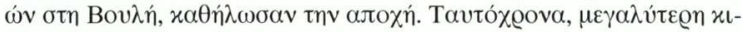

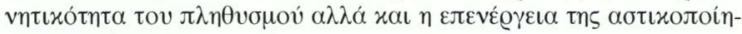

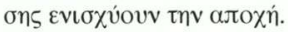

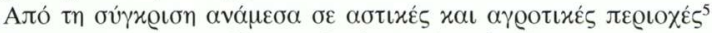

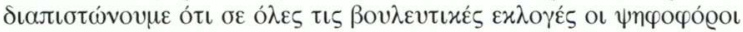

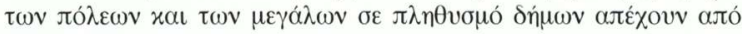

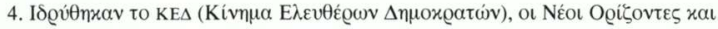

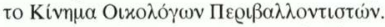

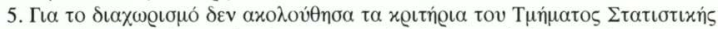

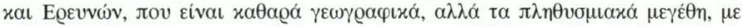

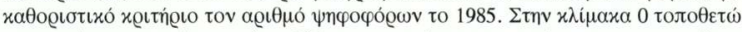

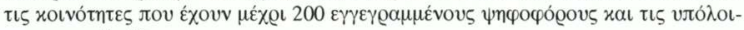

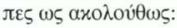

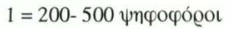

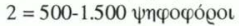

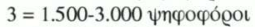

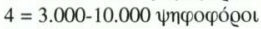

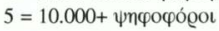

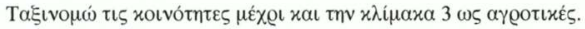




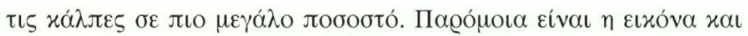

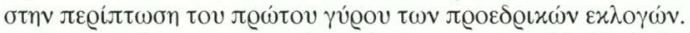

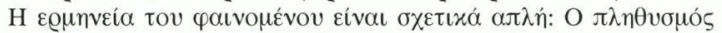

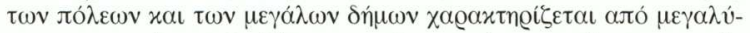

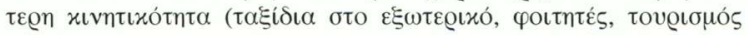

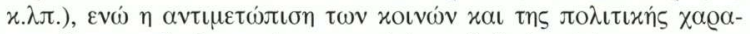

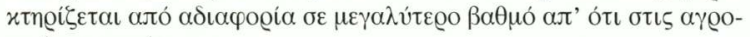

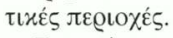

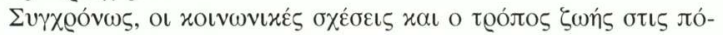

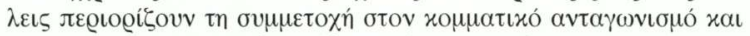

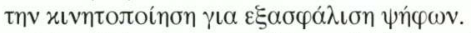

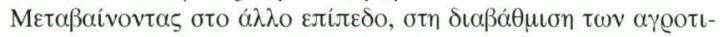

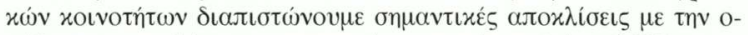

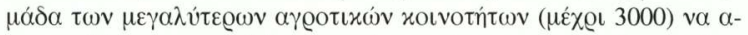

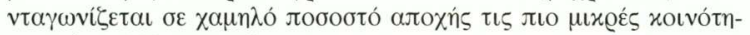

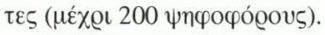

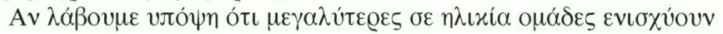

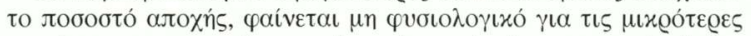

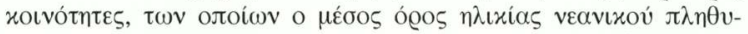

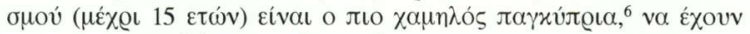

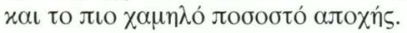

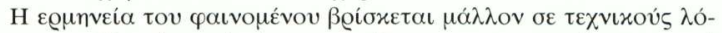

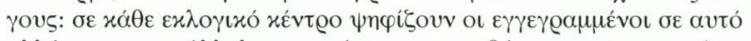

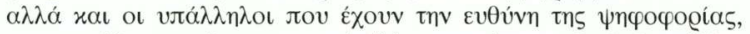

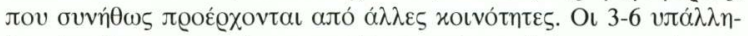

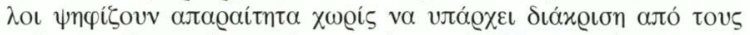

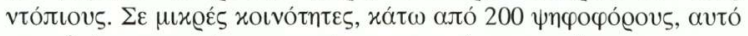

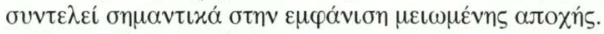

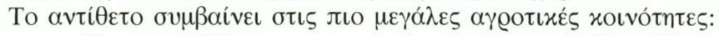

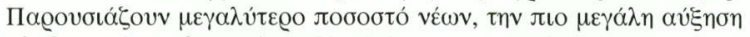

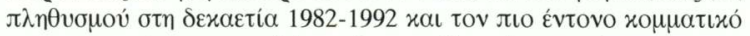

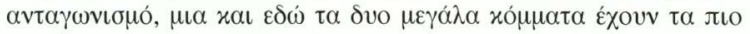

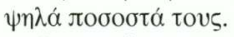

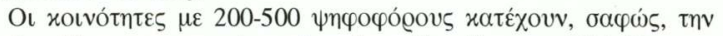

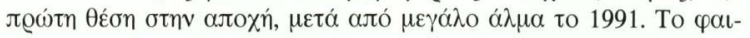

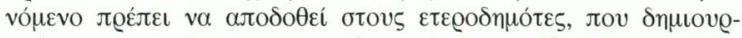

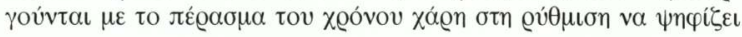

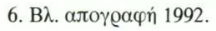




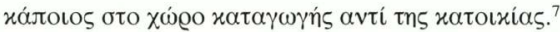

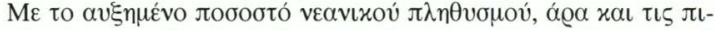

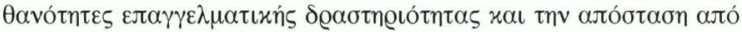

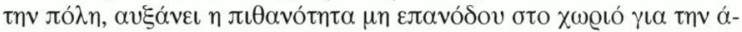

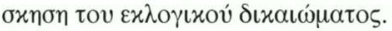

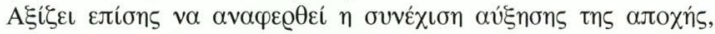

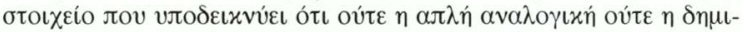

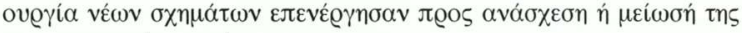

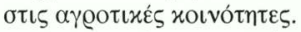

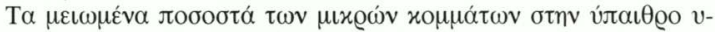

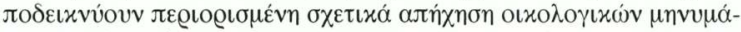

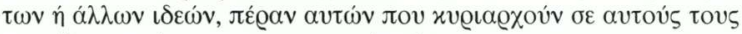

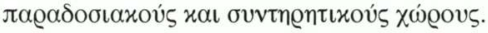

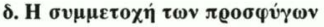

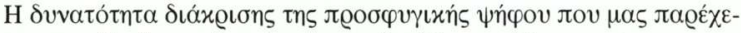

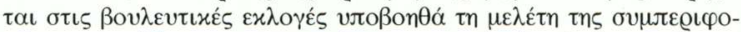

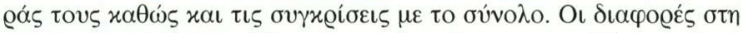

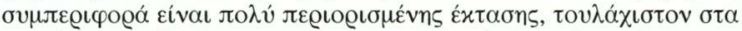

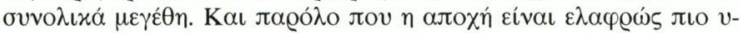

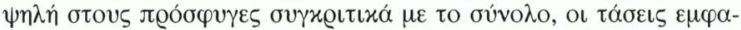

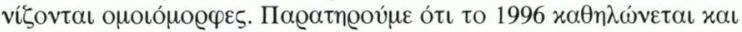

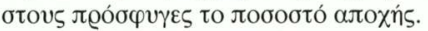

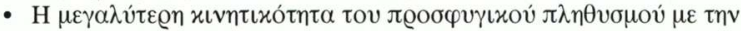

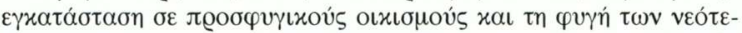

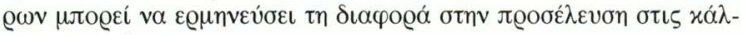
$\pi \varepsilon \varsigma \pi \varrho \circ \sigma \varphi v ́ \gamma \omega v$ xa $\mu \eta$.

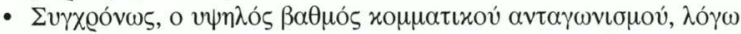

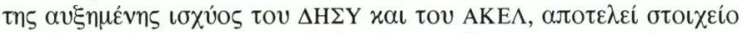

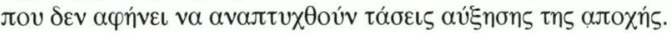

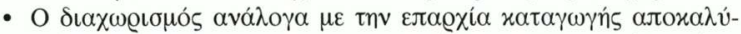

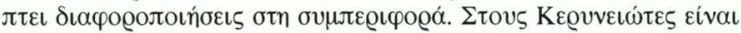

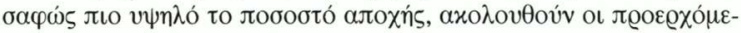

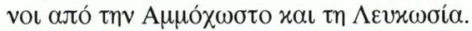

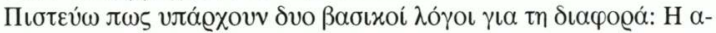

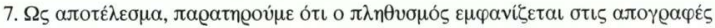

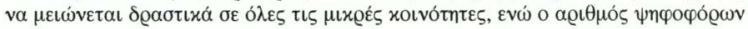

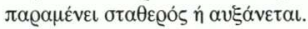




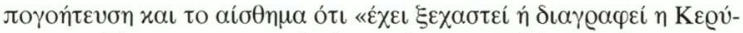

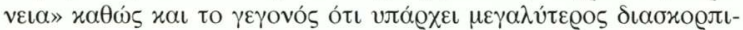

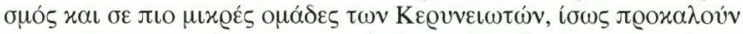

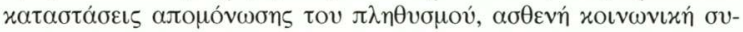

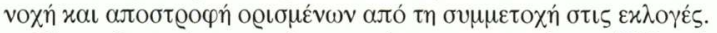

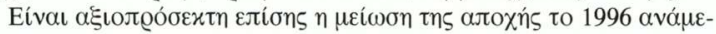

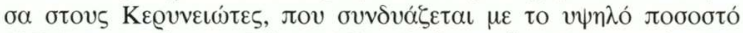

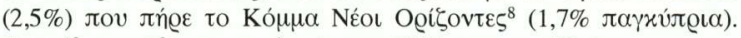

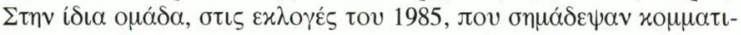

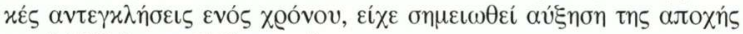

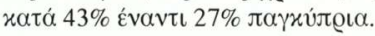

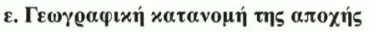

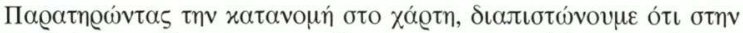

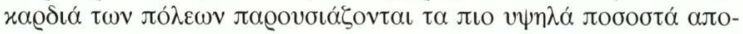

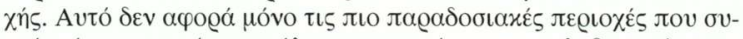

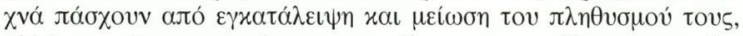

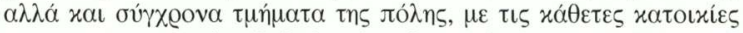

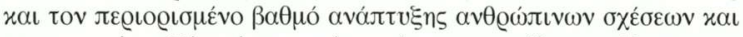

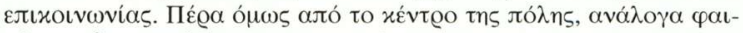

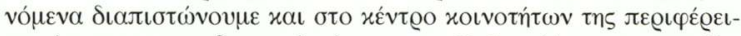

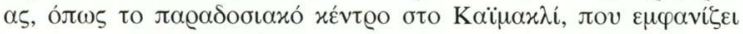

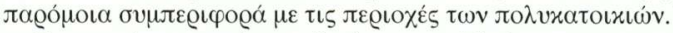

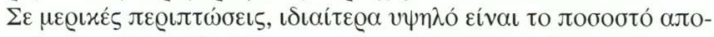

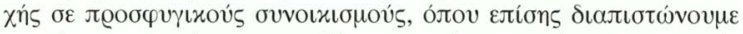

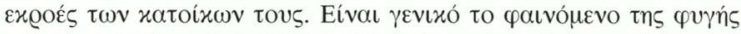

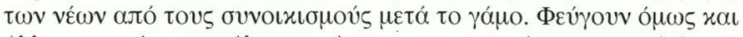

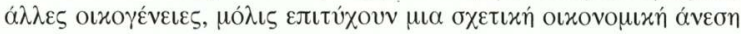

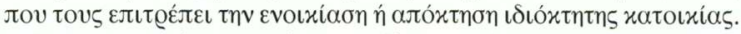

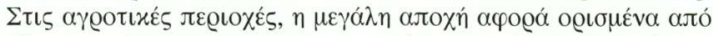

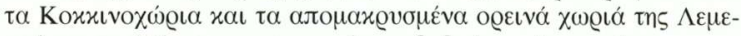

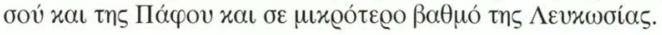

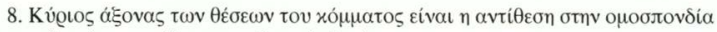

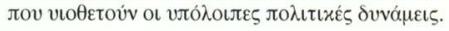




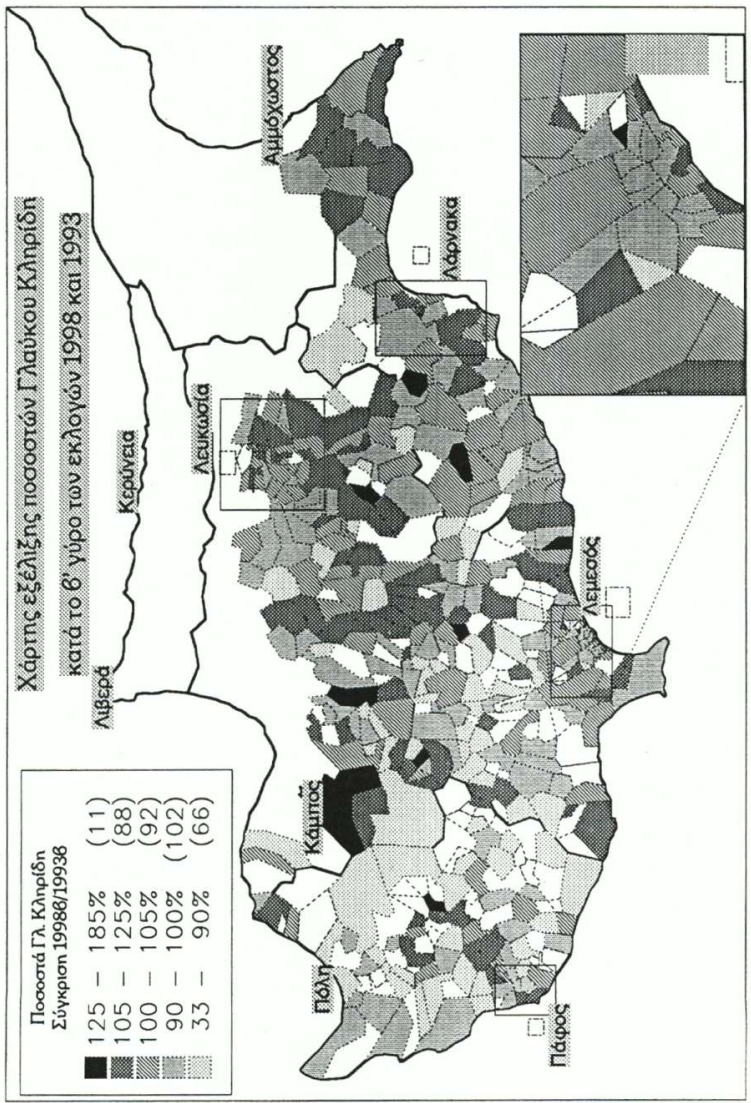




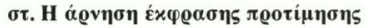

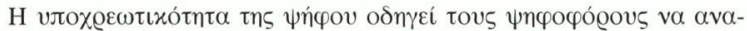

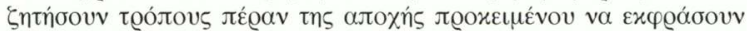

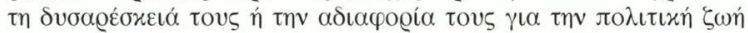

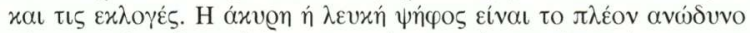

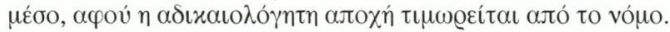

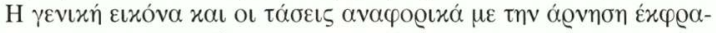

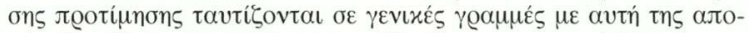

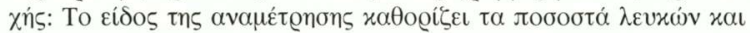

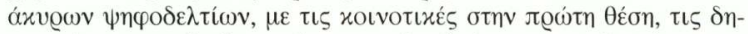

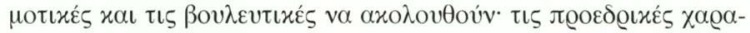

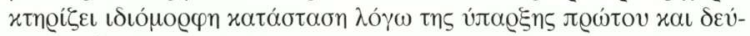

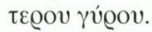

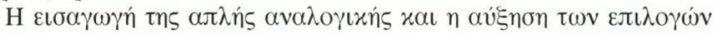

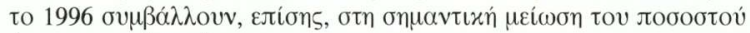

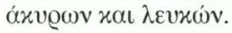

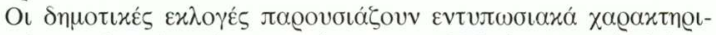

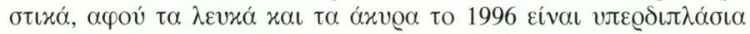

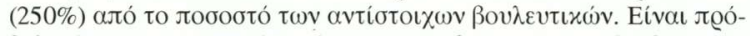

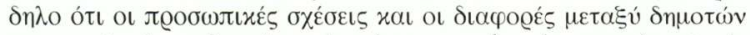

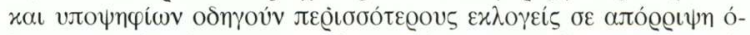

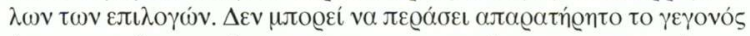

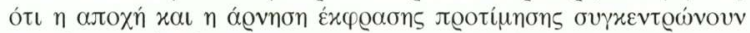

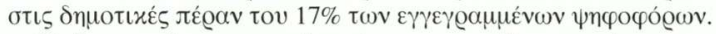

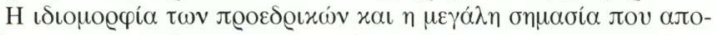

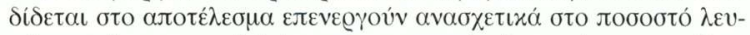

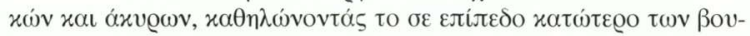

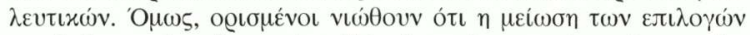

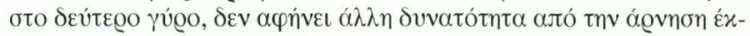

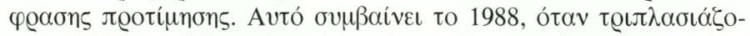

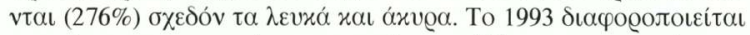

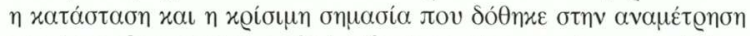

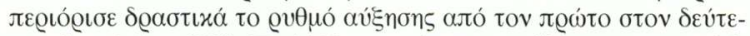

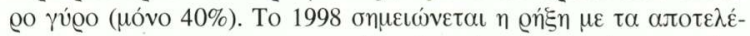

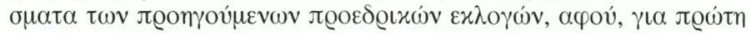

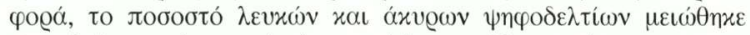

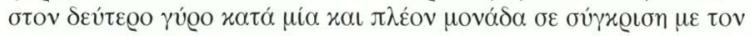

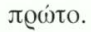




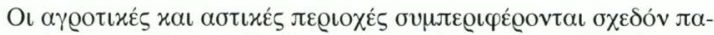

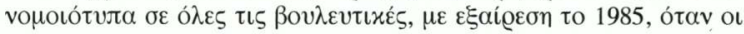

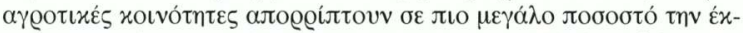

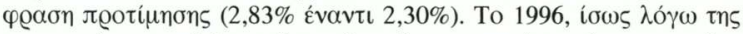

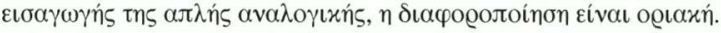

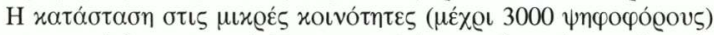

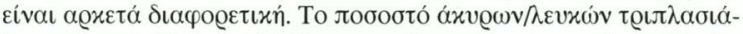

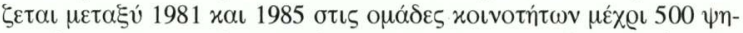

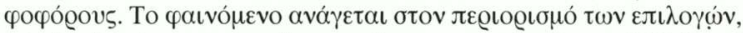

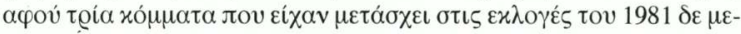

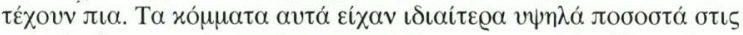

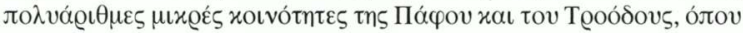

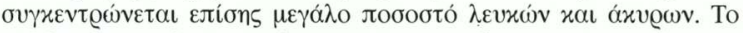

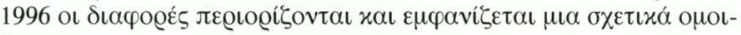
ó

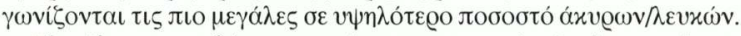

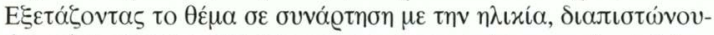

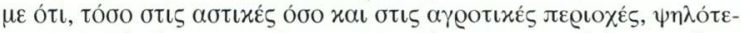

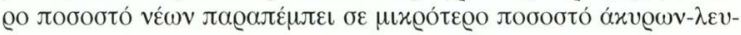

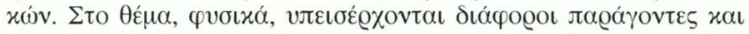

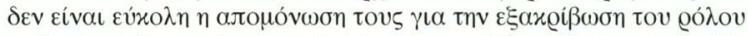

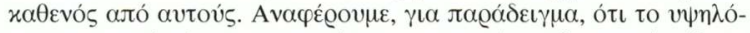

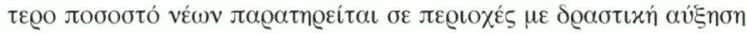

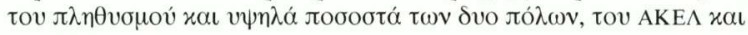

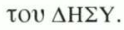

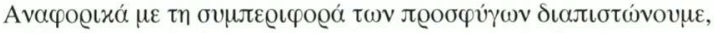

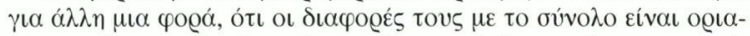

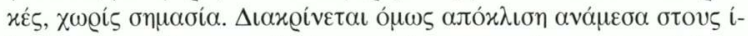

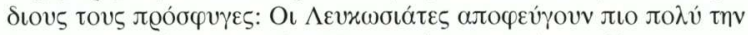

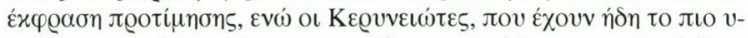

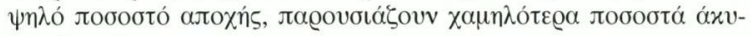

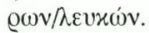

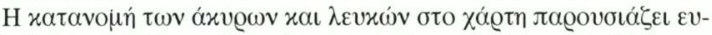

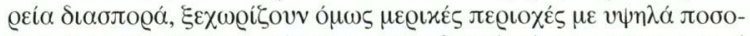

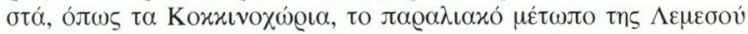

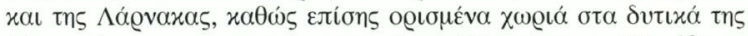

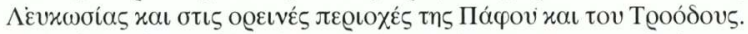

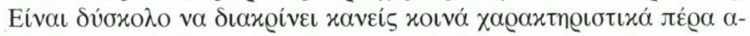

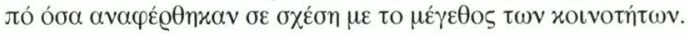




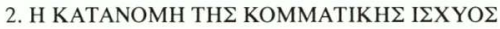 \\ $\alpha$. Гevixó}

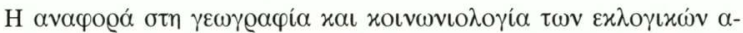

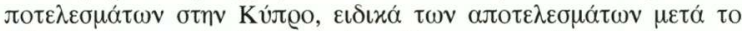

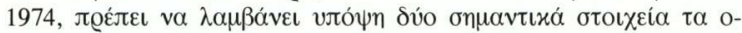

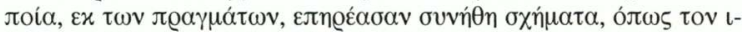

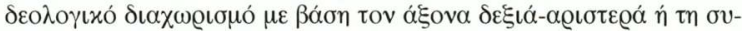

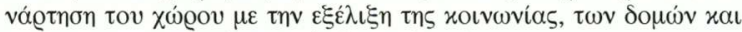

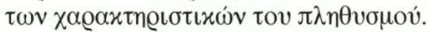

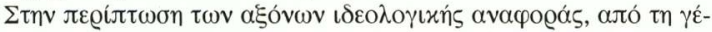

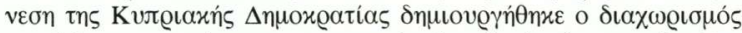

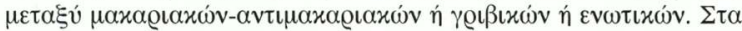

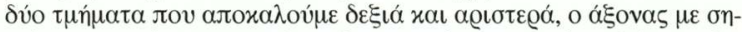

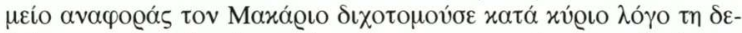

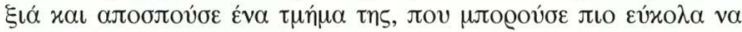

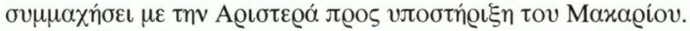

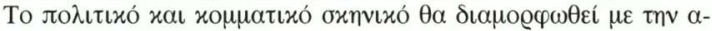

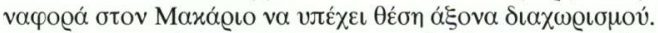

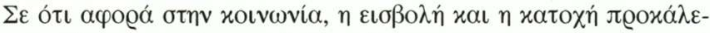

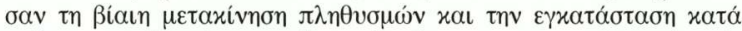

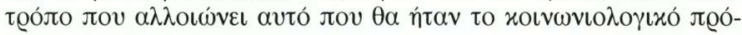

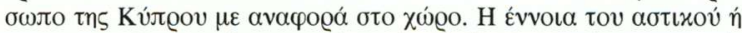

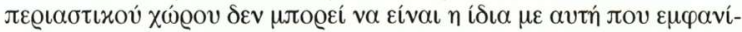

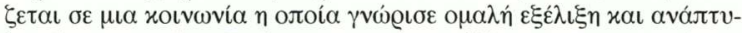

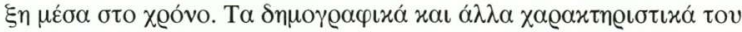

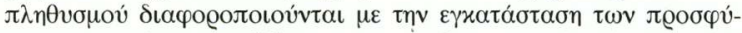

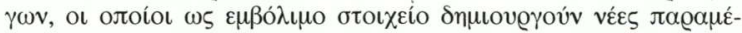

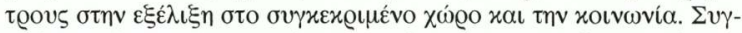

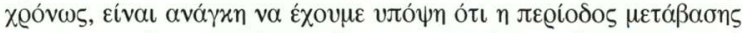

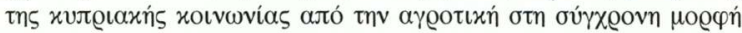

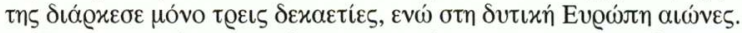

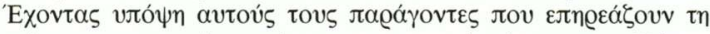

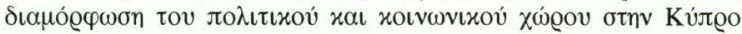

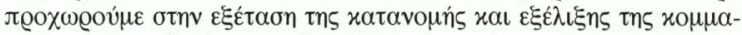

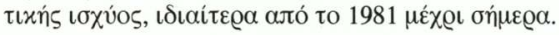




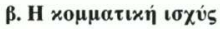

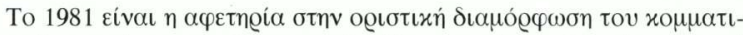

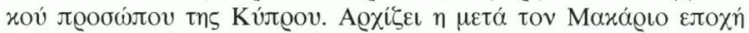

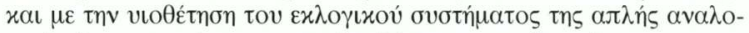

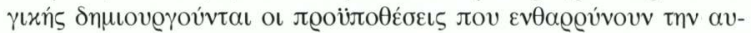

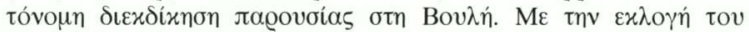

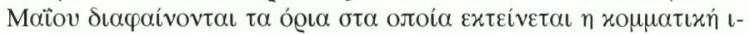

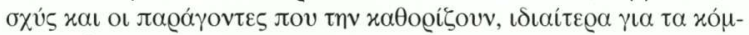

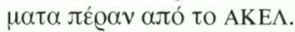

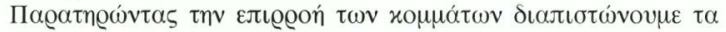

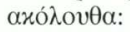

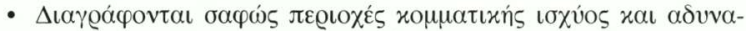

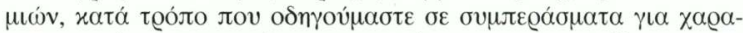

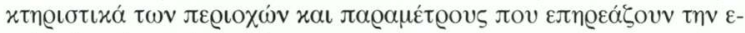

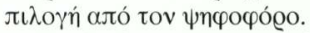

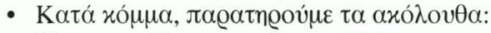

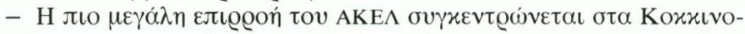

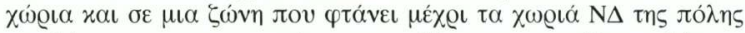

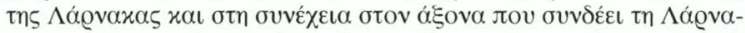

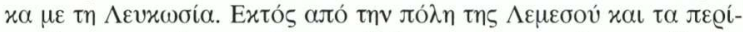

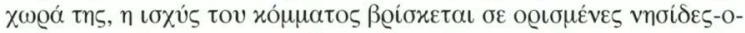

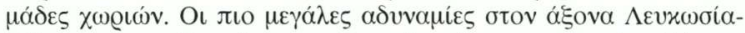

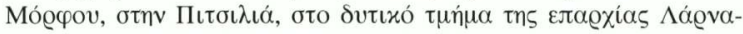

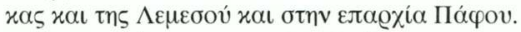

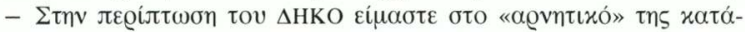

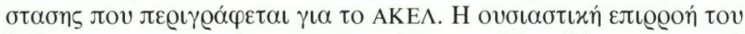

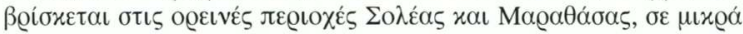

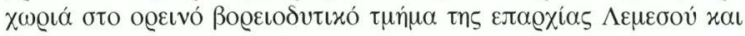

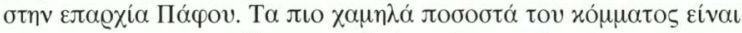

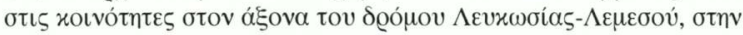

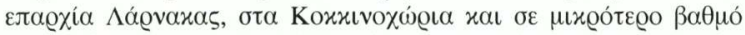

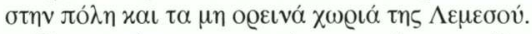

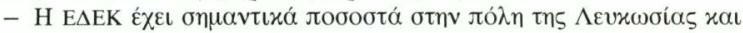

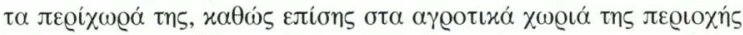

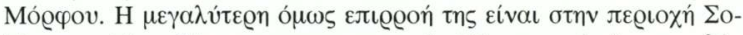

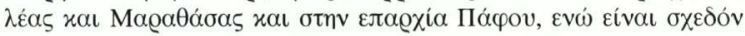

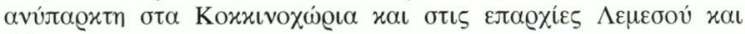
$\Lambda \alpha$ @vaxas. 


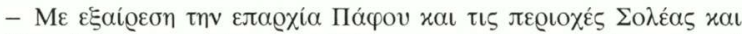

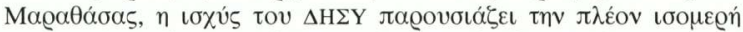

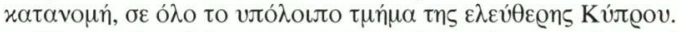

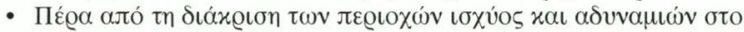

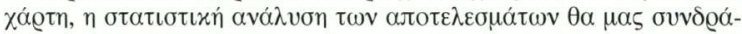

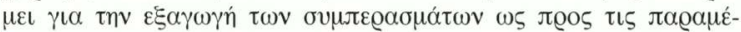

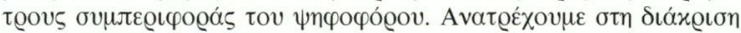

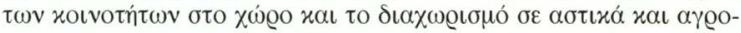

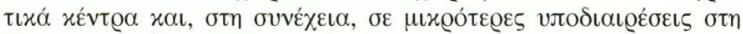

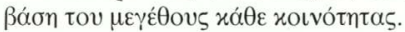

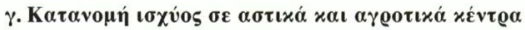

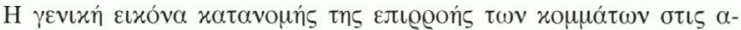

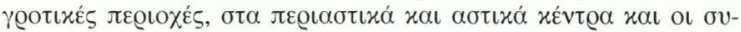

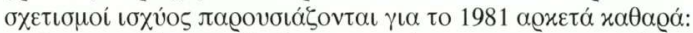

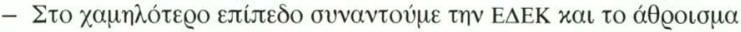

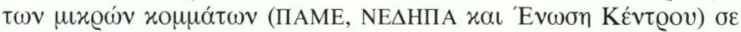

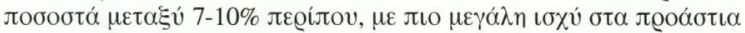

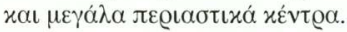

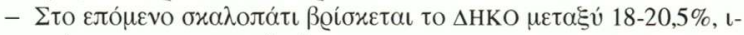

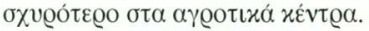

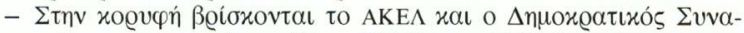

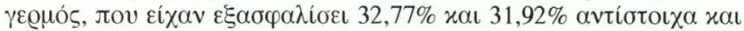

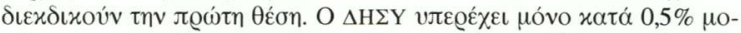

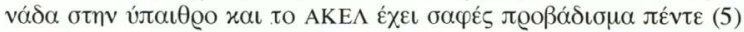

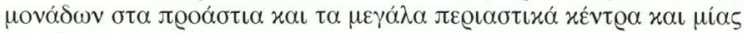

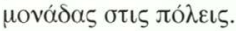

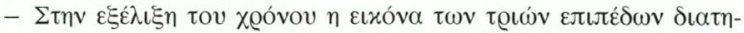

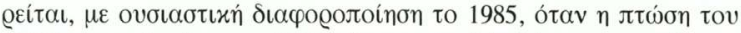

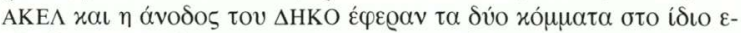

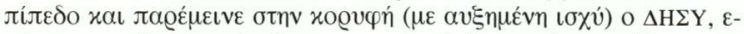

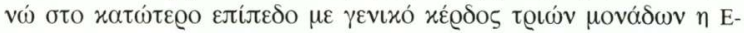
$\triangle \mathrm{EK}$.

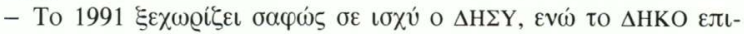

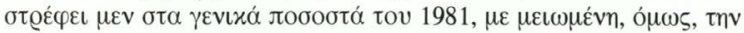

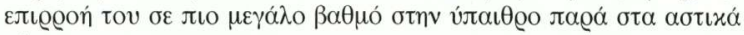

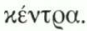

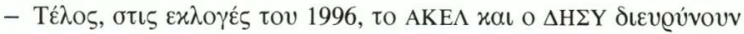




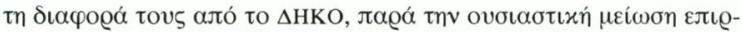

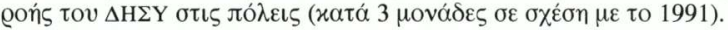

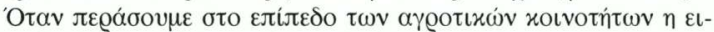

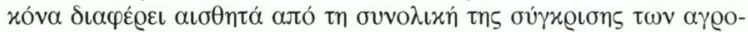

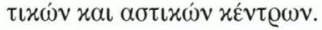

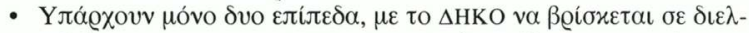

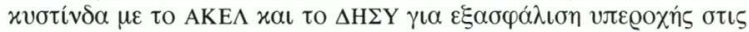

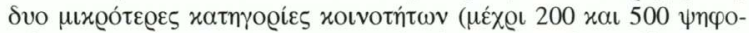

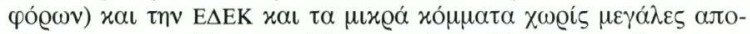

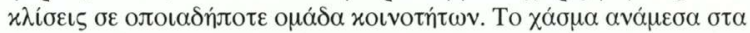

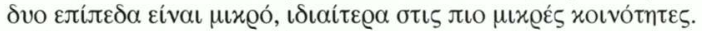

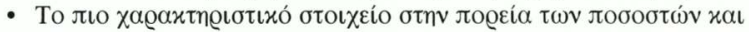

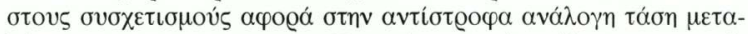

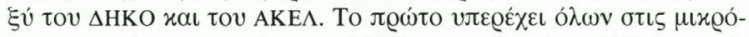

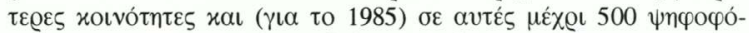

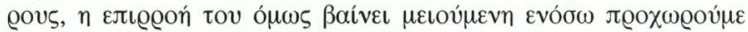

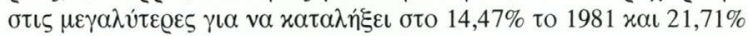

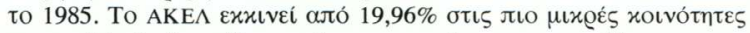

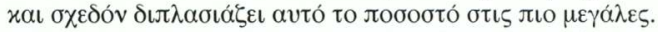

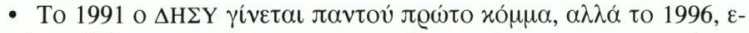
vஸ́

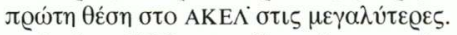

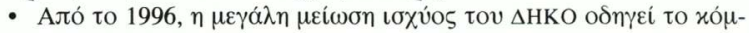

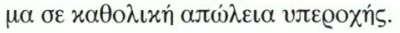

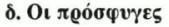

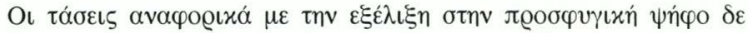

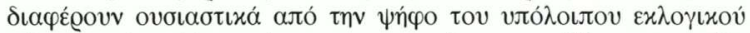

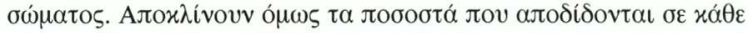

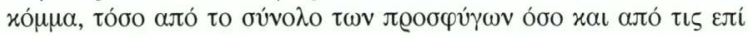

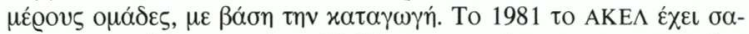

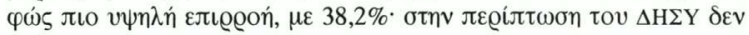

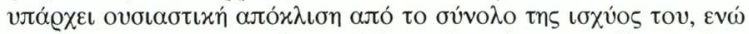

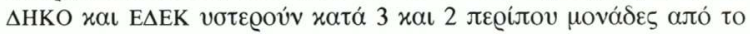

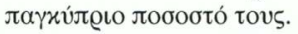

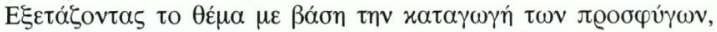

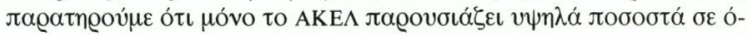

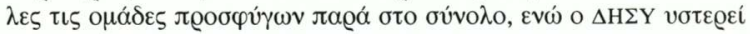




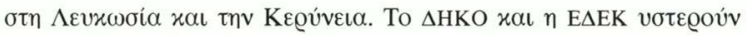

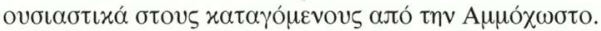

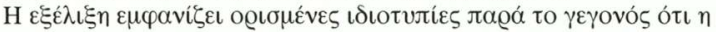

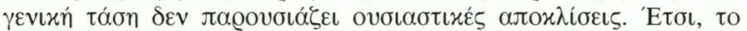

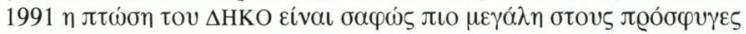

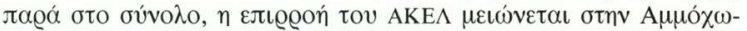

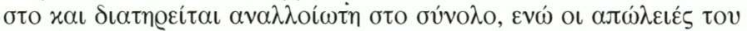

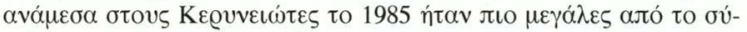

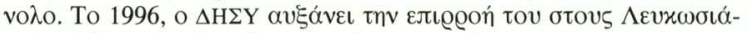

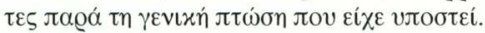

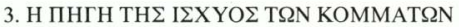

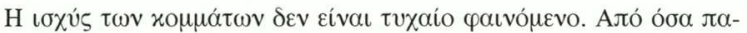

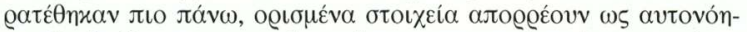

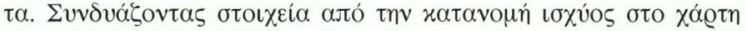

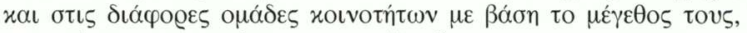

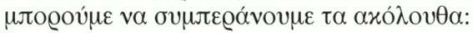

\section{a. TO AKEA}

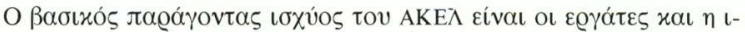

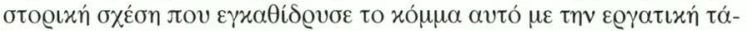

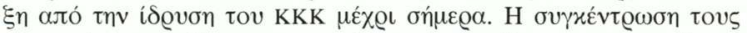

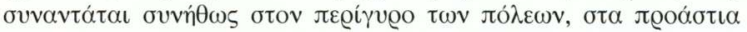

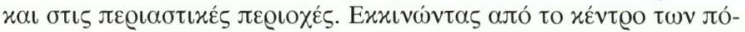

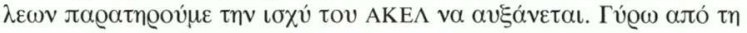
$\Lambda \varepsilon v$

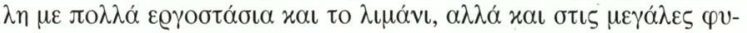

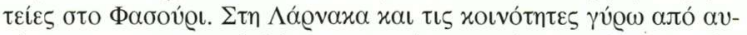

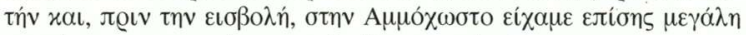

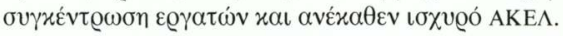

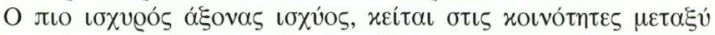

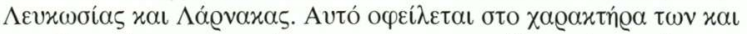

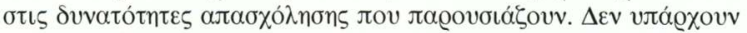

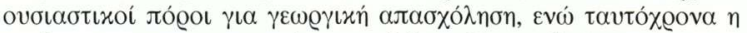

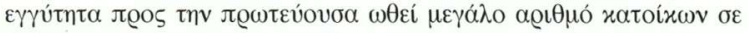

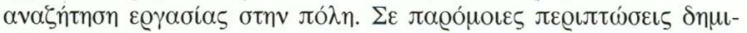




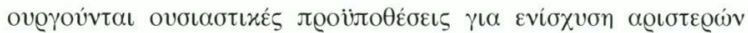

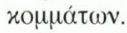

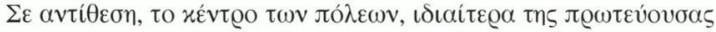

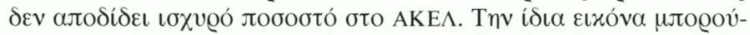

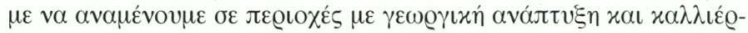

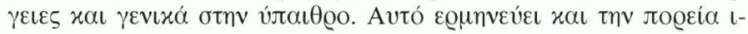

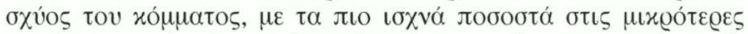

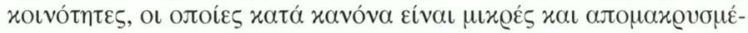

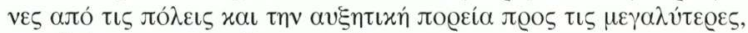

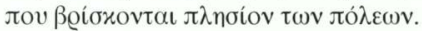

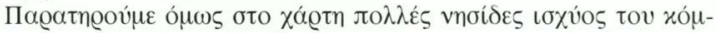

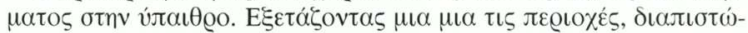

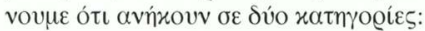

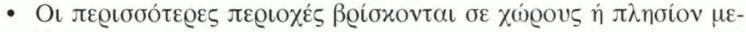

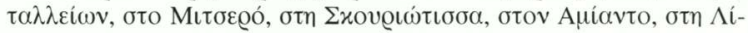

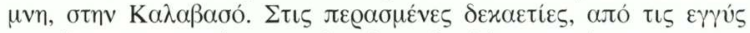

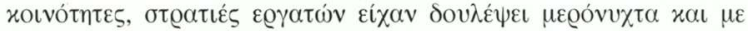

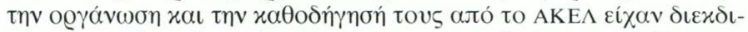

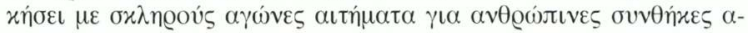

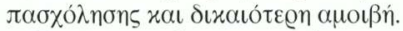

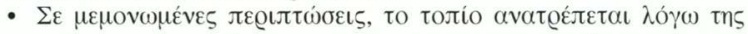

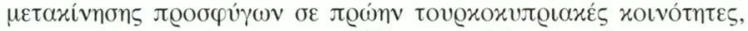

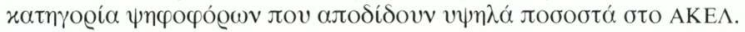

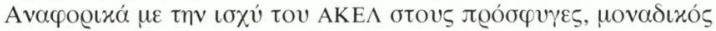

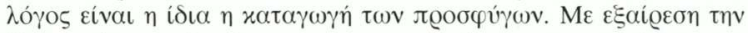

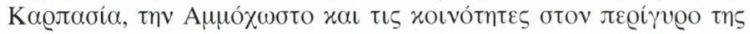

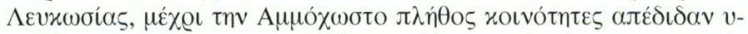

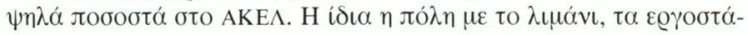

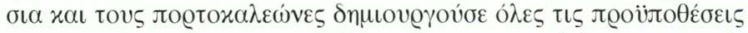

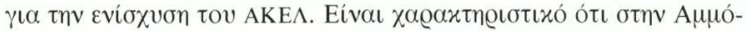

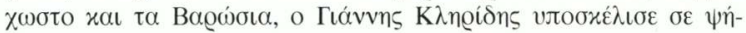

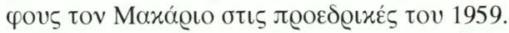

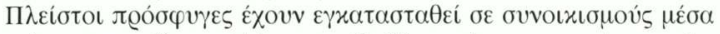

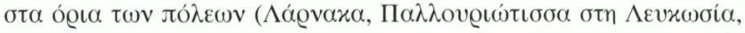

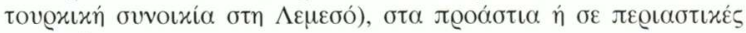

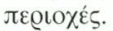




\section{в. То АHKO}

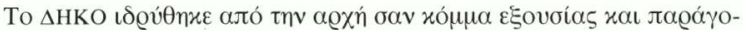

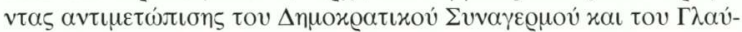

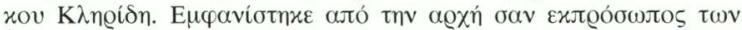

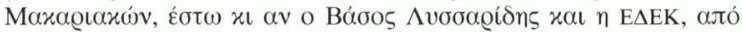

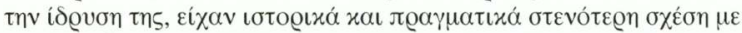
тov Maxáoto.

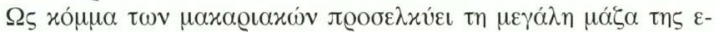

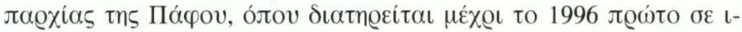

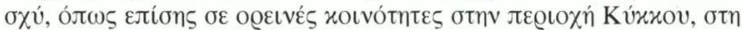

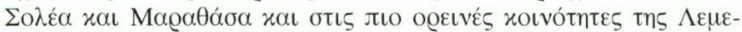

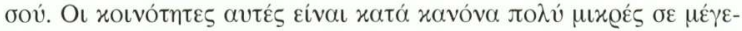

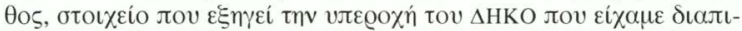

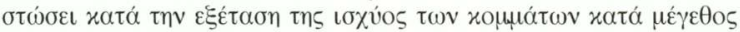

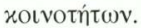

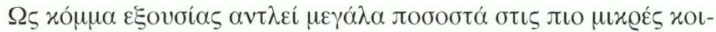

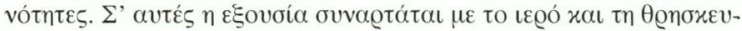

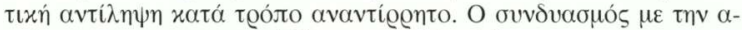

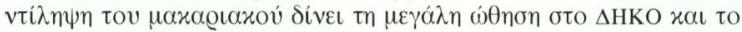

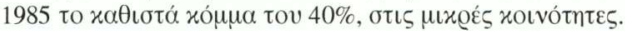

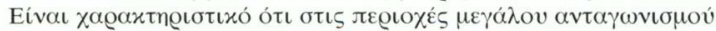

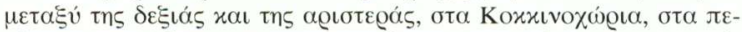

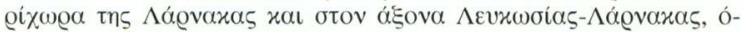

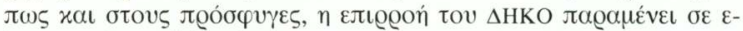

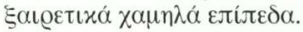

\section{$\gamma . \mathrm{O} \Delta \mathrm{HLY}$}

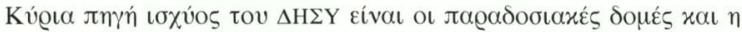

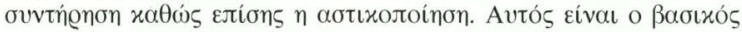

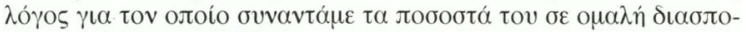

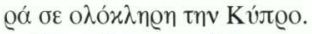

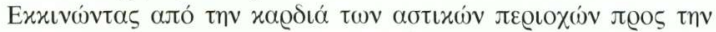

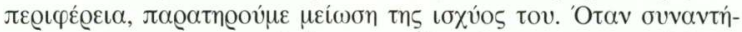

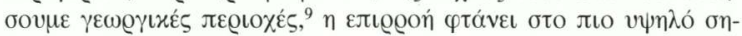

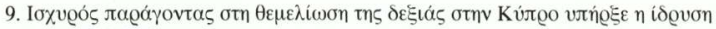

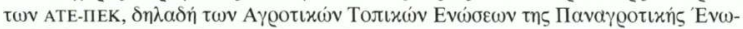

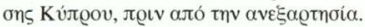




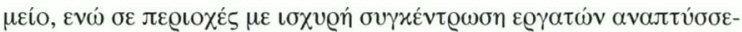

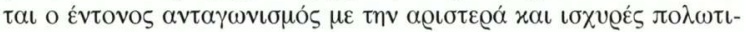

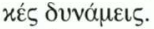

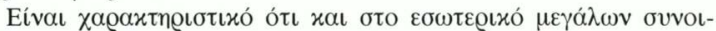

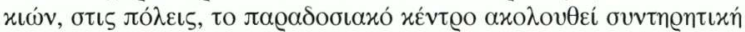

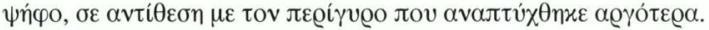

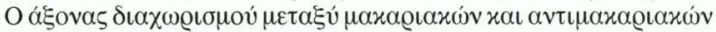

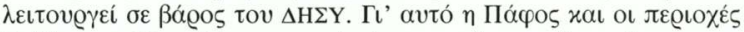

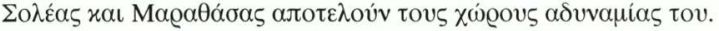

\section{ס. H EAEK}

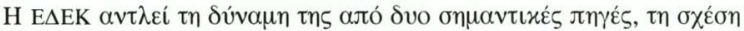

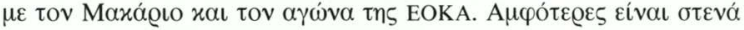

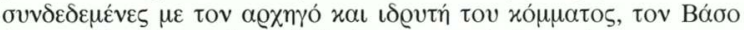

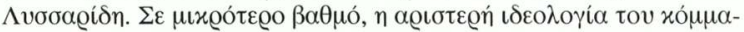

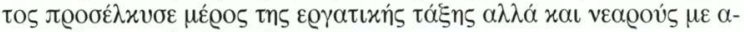

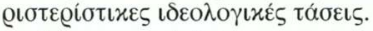

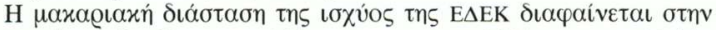

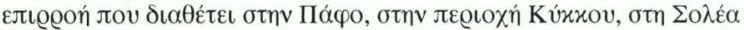

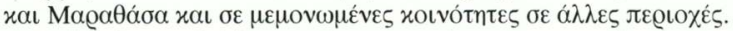

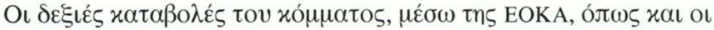

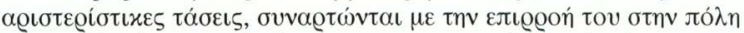

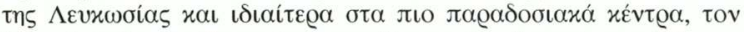

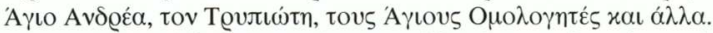

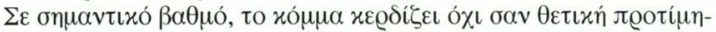

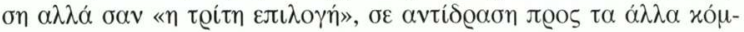

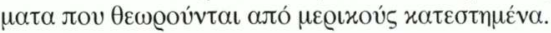

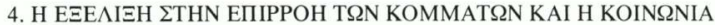

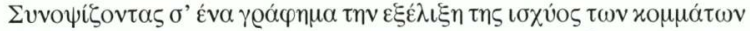

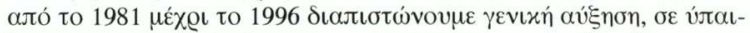

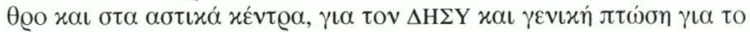

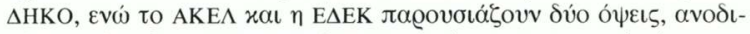

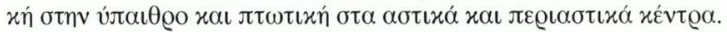

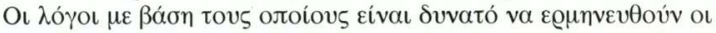

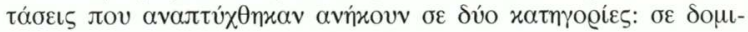




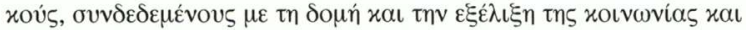

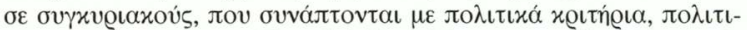

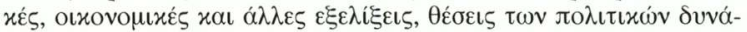

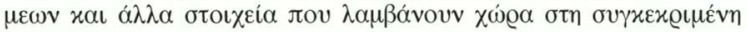
$\pi \varepsilon$ gíodo.

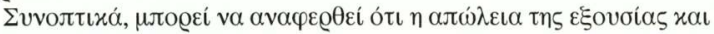

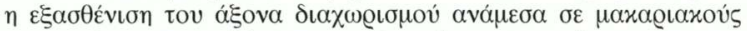

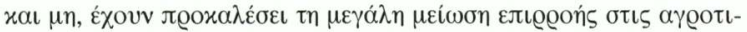

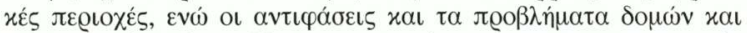

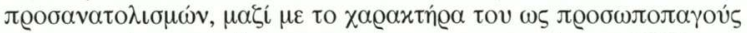

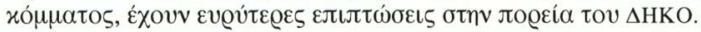

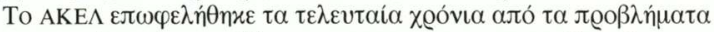
$\pi \varrho о \sigma \alpha v \alpha \tau$ to

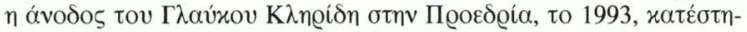

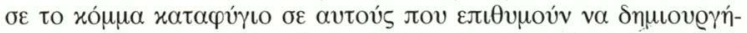

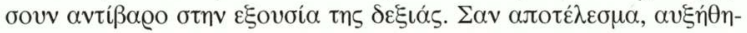

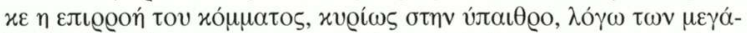

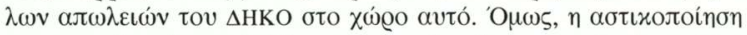

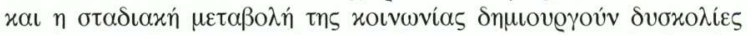

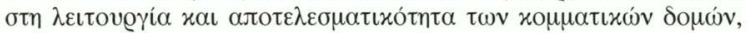

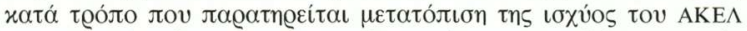

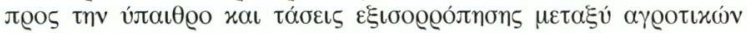

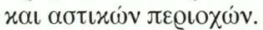

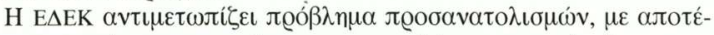

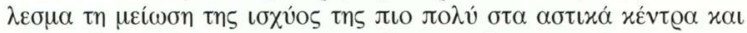

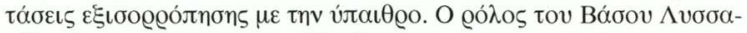

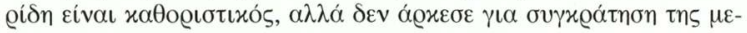

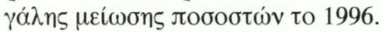

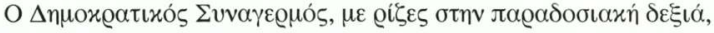

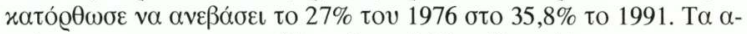

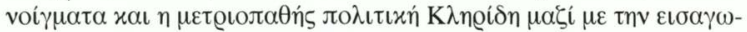

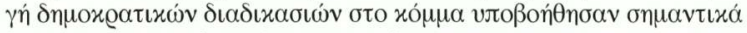

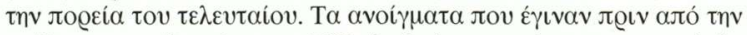

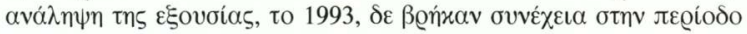

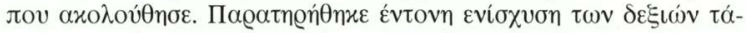

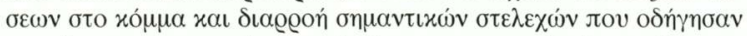

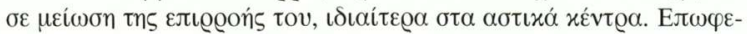

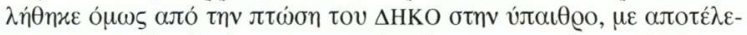

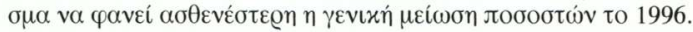

